\title{
Anacardic acid enhances the anticancer activity of liposomal mitoxantrone towards melanoma cell lines - in vitro studies [Corrigendum]
}

\author{
Legut M, Lipka D, Filipczak N, et al. Int J Nanomedicine. 2014;9:653-668.
}

The authors advise the Acknowledgment on page 666 is missing the final sentence:

This study was supported by: the Wrocław Research Centre EIT+ under the Biotechnologies and Advanced Medical Technologies project; BioMed (POIG.01.01.02-02-003/08), financed by the European Regional Development Fund (Operational Programme Innovative Economy, 1.1.2) \#8221.

International Journal of Nanomedicine

\section{Publish your work in this journal}

The International Journal of Nanomedicine is an international, peerreviewed journal focusing on the application of nanotechnology in diagnostics, therapeutics, and drug delivery systems throughout the biomedical field. This journal is indexed on PubMed Central, MedLine, CAS, SciSearch $®$, Current Contents ${ }^{\circledR} /$ Clinical Medicine,
Journal Citation Reports/Science Edition, EMBase, Scopus and the Elsevier Bibliographic databases. The manuscript management system is completely online and includes a very quick and fair peer-review system, which is all easy to use. Visit http://www.dovepress.com testimonials.php to read real quotes from published authors. 